The textural observations in the granites of the Ivisârtoq region support the textural interpretations made by Hibbard (1979).

There are, as is to be expected, several problems. First, myrmekite in the deformed Nûk granites shows no evidence of deformation. However, the same problem would apply to a subsolidus model unless the myrmekite is envisaged as having developed several hundred million years after intrusion of the granites. Secondly, the question as to why extensive subsolidus recrystallisation has not taken place still exists. If it is assumed that the granites cooled slowly in the presence of fluids, metamorphic re-equilibration would be expected. Fluids can be seen to have been replacing narrow grain-boundary zones even after the development of perthite. However, only very limited areas were affected.

\title{
References
}

Hibbard, M. J. 1979: Myrmekite as a marker between preaqueous and postaqueous phase saturation in granitic systems. Bull. geol. Soc. Am. 90, 1047-1062.

Jahns, R. H. \& Burnham, C. W. 1969: Experimental studies of pegmatite genesis: I. A model for the derivation and crystallisation of granite pegmatites. Econ. Geol. 64, 843-864.

Phillips, E. R. 1974: Myrmekite - one hundred years later. Lithos 7, 181-194.

Robertson, S. 1983: Provisional results of isotope investigations into quartzo-feldspathic rocks from Kangiussap nunâ, Ivisârtoq sheet, southern West Greenland. Rapp. Grønlands geol. Unders. 115, $56-59$.

Department of Geology,

The University,

Exeter EX4 $4 Q E$,

U.K.

\section{A textural study of Archaean peridotites; Ujaragssuit nunât, Ivisârtoq region, southern West Greenland}

\author{
Martin A. Crewe
}

Recent mapping of Ujaragssuit nunât by Chadwick \& Crewe (1982) and Chadwick et al. (1983), following reconnaissance work by Allaart et al. (1977), has demonstrated the widespread occurrence of supracrustal lithologies. Ujaragssuit nunât is situated immediately to the north-west of Ivisârtoq, which has been described in some detail by Friend \& Hall (1977) and Hall (1980, 1981). Friend \& Hall (1977) noted that the Akilia association ultramafic rocks can be divided into two groups. The first group comprises those rocks rich 
in olivine or its hydrous alteration products. Ultramafic rocks of the second group are olivine-free, being composed mainly of hornblende with or without clinopyroxene; these rocks are not considered further in this report. A similar division has been proposed for the ultramafic rocks of the Ivisârtoq Amphibolite Complex (Friend \& Hall, 1977) which has been correlated with the Malene supracrustal rocks of the Godthåb region. A layered ultrabasic-gabbroic formation has also been reported from Ivisârtoq (Friend \& Hall, 1977). In Ujaragssuit nunât no unequivocal evidence of a layered complex has been observed but the two-fold division of both the Akilia association and Malene ultramafic rocks is believed to be fundamental.

Ultramafic bodies are sometimes preserved in strips of supracrustal rocks where they are associated with abundant amphibolite or, more rarely, paragneisses. Contacts are generally concordant although Nutman et al. (1983) and Brewer et al. (this report) have reported ultramafic sheets cross-cutting other supracrustal rocks. Inclusions of ultramafic rock in orthogneisses have conformable contacts of indecipherable origin. Most of the ultramafic rocks in Ujaragssuit nunât are homogeneous but tectonic fabrics are locally well-developed.

Friend \& Hughes (1978) recorded that in the Fiskenæsset region preservation of an anhydrous mineralogy (olivine, pyroxenes and spinels) is rare and only found in the cores of the larger ultramafic bodies that are preserved within extensive amphibolite outcrops. In Ujaragssuit nunât preservation of anhydrous minerals is generally good within the cores of even the smallest bodies, whether they are surrounded by amphibolites or by gneisses.

\section{Petrography}

Modal analysis of 44 samples reveals that both Malene and Akilia association ultramafic rocks contain little clinopyroxene. The dominant rock types are spinel-bearing harzburgite and spinel-bearing dunite (spinel rarely exceeds $5 \%$ in the mode); two samples are classified as Iherzolites (Streckeisen, 1976). There is no evidence of preferential replacement of clinopyroxene compared with orthopyroxene. The major hydrous phases that are present are serpentine (optically determined to be antigorite), clino-amphiboles, talc and phlogopite; magnesite, anthophyllite and chlorite are minor constituents. Textural interpretation was found to be effective only where hydrous minerals make up less than $50 \%$ of the rock, a condition satisfied by 18 of the 25 Akilia association samples and 9 of the 19 Malene ultramafic rocks.

The average grain size of the Akilia association ultramafic rocks is $2-3 \mathrm{~mm}$ but significantly larger grains of both olivine and orthopyroxene are not uncommon. Olivine with undulose extinction is observed in some thin sections but the formation of sub-grains is very limited. Grain boundaries seen in thin section are usually curvilinear while rounded spinel inclusions in olivine are ubiquitous. Orthopyroxene often contains tiny blebs of spinel (fig. 30), a texture which has been attributed to exsolution (Mercier \& Nicolas, 1975; Brown et $a l ., 1980$ ). A very common feature in the harzburgites is the enclosing of rounded olivines by orthopyroxene (fig. 31).

Most samples of Malene ultramafic rocks preserve textures similar to those described above but some consist of a distinctive mosaic of polygonal grains (fig. 32). Garde et al. (1983) reported apparently similar textures from the Malene ultramafic rocks of the Isukasia area. The grain size of the Ujaragssuit nunât samples is $1 \mathrm{~mm}$ and there is little variation. 

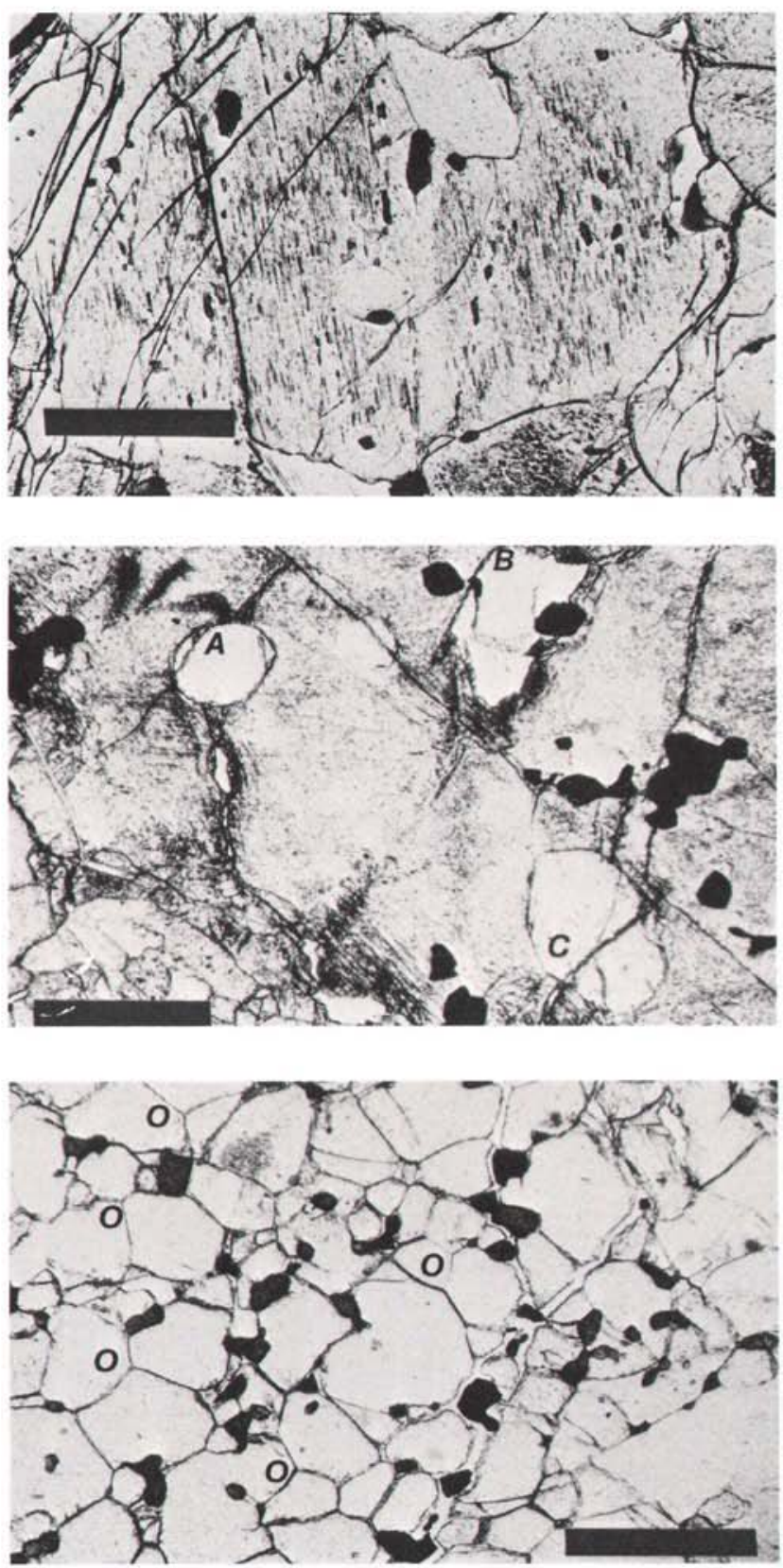

Fig. 30. Grain of orthopyroxene with fine blebs of spinel apparently due to exsolution. Scale bar is $0.2 \mathrm{~mm}$ long.

Fig. 31. Poikilitic orthopyroxene grain enclosing anhedral spinels and olivines. Olivine grains $\mathrm{A}$ and $\mathrm{B}$ are in optical continuity but grain $\mathrm{C}$ is not. Scale bar is $0.4 \mathrm{~mm}$ long.

Fig. 32. Olivines and orthopyroxenes in equigranular texture with common $120^{\circ}$ angles between grains $(\mathrm{O})$. Brown spinel grains are usually located at grain boundaries. Scale bar is $0.4 \mathrm{~mm}$ long. 
Rounded spinels are scattered throughout and are either included in olivine and orthopyroxene or located at grain boundaries.

\section{Origin}

The most striking feature of the ultramafic rocks described is their refractory nature: even high degrees of partial melting can not generate such olivine-rich rocks. Peridotites of this type are commonly formed by one of two processes: extreme fractionation of basic magma in a cumulate sequence or as mantle residua after extraction of partial melt(s).

The mosaic texture preserved in some samples of Malene ultramafic rocks is clearly of metamorphic origin. Similar textures have been reported from both mantle xenoliths and the basal portions of layered intrusions. The enclosing of rounded olivines by orthopyroxene is quite common in cumulate rocks but may also be a primary mantle texture (Rothstein, 1977). The differentiation between ultramafic rocks of cumulate and mantle origins is by no means simple.

Nicolas et al. (1980) attempted to distinguish mantle peridotites from deformed ultramafic cumulates. The colour and mode of occurrence of the spinel and the abundance of diopside were found to be the most useful diagnostic features. The ultramafic rocks considered here contain very little clinopyroxene and a brown spinel which is often associated with orthopyroxene. These features are those ascribed by Nicolas et al. (1980) to mantle peridotites.

\section{Conclusions}

It is tentatively concluded that both Malene and Akilia association olivine-rich ultramafic rocks originated as mantle residua after extraction of partial melt(s). This proposition is in accord with the findings of Friend \& Hughes (1978). They envisaged a tectonic emplacement of the mantle rocks but the field evidence indicates that this is not always the case.

\section{References}

Allaart, J. H., Jensen, S. B., McGregor, V. R. \& Walton, B. J. 1977: Reconnaissance mapping for the 1:500 000 map sheet in the Godthåb-Isua region, southern West Greenland. Rapp. Grønlands geol. Unders. 85, 50-54.

Brewer, M., Chadwick, B., Coe, K. \& Park, J. F. W. 1984: Further field observations in the Ivisârtoq region of southern West Greenland. Rapp. Gronlands geol. Unders. 120 (this report).

Brown, G. M., Pinsent, R. H. \& Coisy, P. 1980: The petrology of spinel-peridotite xenoliths from the Massif Central, France. Am. J. Sci. 280-A, 471-498.

Chadwick, B. \& Crewe, M. A. 1982: Field work in the Ujaragssuit nunât area, Ivisârtoq region, inner Godthåbsfjord, southern West Greenland. Rapp. Grønlands geol. Unders. 110, 57-63.

Chadwick, B., Crewe, M. A. \& Park, J. F. W. 1983: Field work in the north of the Ivisârtoq region, inner Godthåbsfjord, southern West Greenland. Rapp. Grønlands geol. Unders. 115, 49-56.

Friend, C. R. L. \& Hall. R. P. 1977: Field work in the Ivisârtoq area, inner Godthåbsfjord, southern West Greenland. Rapp. Grønlands geol. Unders. 85, 54-60.

Friend, C. R. L. \& Hughes, D. J. 1978: Relict plutonic textures in Archaean ultramafic rocks from the Fiskenæsset region, southern West Greenland; implications for crustal thickness. In Windley, B. F. \& 
Naqvi, S. M. (edit.), Archaean Geochemistry. Developments in Precambrian geology. 1, 375-392. Amsterdam: Elsevier.

Garde, A. A., Hall, R. P., Hughes, D. J., Jensen, S. B., Nutman, A. P. \& Stecher, O. 1983: Mapping of the Isukasia sheet, southern West Greenland. Rapp. Grønlands geol. Unders. 115, 20-29.

Hall, R. P. 1980: The tholeiitic and komatiitic affinities of the Malene metavolcanic amphibolites from Ivisârtoq, southern West Greenland. Rapp. Grønlands geol. Unders. 97, 20 pp.

Hall, R. P. 1981: The Archaean geology of Ivisârtoq, inner Godthåbsfjord, southern West Greenland. Unpubl. Ph. D. thesis, Council for National Academic Awards, Portsmouth Polytechnic.

Mercier, J-C. C. \& Nicolas, A. 1975: Textures and fabrics of upper-mantle peridotites as illustrated by xenoliths from basalts. J. Petrol. 16, 454-487.

Nicolas, A., Boudier, F. \& Bouchez, J. L. 1980: Interpretation of peridotite structures from ophiolitic and oceanic environments. Am. J. Sci. 280-A, 192-210.

Nutman, A. P., Bridgwater, D., Dimroth, E., Gill, R. C. O. \& Rosing, M. 1983: Early (3700 Ma) Archaean rocks of the Isua supracrustal belt and adjacent gneisses. Rapp. Grønlands geol. Unders. 112, 5-22.

Rothstein, A. T. V. 1977: The distribution and origin of primary textures in the Lizard peridotite, Cornwall. Proc. Geol. Assoc. 88, 93-105.

Streckeisen, A. 1976: To each plutonic rock its proper name. Earth-Sci. Rev. 12, 1-33.

Department of Geology,

The University,

Exeter EX4 $4 Q E$,

U. K.

\title{
An iron-formation in the Precambrian Tartoq Group, South-West Greenland
}

\author{
Peter W. Uitterdijk Appel
}

During the 1950s and early 1960s the Ivigtut area was mapped by the Geological Survey of Greenland (GGU), as part of GGUs systematic mapping programme. Detailed work was carried out on the two supracrustal units in the area, and the relative age relationship of the two units was established. The younger Ketilidian supracrustal rocks outcrop in the inland area, close to the Inland Ice, and the older Tartoq Group supracrustal rocks are found in and around Sermiligârssuk fjord. In the early 1970s Renzy Mines Ltd. conducted a mineral exploration programme in the area, during which arsenopyrite-pyrite mineralisations were found in the Tartoq Group supracrustals (Appel \& Secher, 1984), and a banded ironformation was discovered in the Ketilidian supracrustal rocks (Appel, 1974). During the 1983 field season two teams from GGU undertook field work in the area, as a result of which a banded iron-formation was discovered in the Tartoq Group supracrustal rocks. 